\title{
Homes of Origin: \\ Return and Property Rights in \\ Post-Dayton Bosnia and Herzegovina
}

\author{
LENE MADSEN
}

\begin{abstract}
This paper explores the post-Dayton property regime in Bosnia, as one tool for facilitating return of displaced persons and refugees. Implementation of post-Dayton property laws, intended to facilitate return, is explored, and few successes are found. Reformed property laws-subject of much attention and chief drain on resources of the international community - remain a legal framework on paper only, and have not delivered minority return. In conclusion, the international community must expand its focus beyond minority return, to the broader concept of "durable solutions." Acknowledging that some displaced persons will not wish to return to their home of origin, the international community should engage in parallel efforts to provide solutions to those who genuinely wish to relocate.
\end{abstract}

\section{Résumé}

Cet article explore le régime des droits à la propriété en Bosnie, un des outils développés dans le but de faciliter le retour des personnes déplacées et des réfugiés. L'article examine ce qui s'est réellement passé dans les faits après l'adoption, suite à l'accord de Dayton, de lois sur la propriété ayant pour but de faciliter le retour, et constate qu'il y a eu très peu de succès. Les réformes apportées aux lois sur la propriété, qui ont accaparé tant d'attention et épuisé si considérablement les ressources de la communauté internationale, restent un cadre légal théorique seulement et n'ont pas apporté, comme escompté, le retour des minorités. L'article conclut que la communauté internationale doit élargir sa vision et aller au-delà de l'objectif du simple retour des minorités pour inclure le concept plus étendu de "solutions durables". La communauté internationale devrait reconnaître la réalité que certains déplacés ne voudront pas retourner à leurs foyers d'origine et devrait entreprendre des démarches parallèles pour proposer des solutions à ceux qui, volontairement et véritablement, choisissent la réinstallation ailleurs.

7 he General Framework Agreement on Peace (GFAP), also known as the Dayton Peace Accords, which in December 1995 concluded a four-year war in Bosnia and Herzegovina, guarantees refugees and displaced people the right to return to their "homes of origin." This guarantee is an essential element of the agreement that brought to a close a war in which displacement was a central-if not the central-goal. Chapter 1, article 1, annex 7 of the GFAP reads,

All refugees and displaced persons have the right to freely return to their homes of origin. They shall have the right to have restored to them property of which they were deprived in the course of hostilities since 1991 and to be compensated for any property that cannot be restored to them. The early return of refugees and displaced persons is an important objective of the settlement of the conflict in Bosnia and Herzegovina. The parties confirm that they will accept the return of such persons who have left the territory, including those who have been accorded temporary protection by third countries. ${ }^{1}$

In the context of Bosnia and Herzegovina (hereafter also referred to as Bosnia or as $\mathrm{BiH}$ ), homes of origin has, for the first time in the history of peace agreements, been interpreted to mean "the physical structure in which one lived before the war." ${ }^{\prime 2}$ Given the sheer magnitude of displacement, this has enormous implications for implementation of the peace agreement, as well as for development of a Bosnian property rights regime. At the end of the war in 
December 1995, some 2.2 million people, or approximately half the pre-war population, had been displaced from their pre-war homes. ${ }^{3}$ A crucial task of the post-Dayton period has been to support and facilitate their return.

To support the return of displaced persons and refugees now is effectively to support "minority return"- that is, return of those who would be in the ethnic minority in the home of origin. The United Nations High Commissioner for Refugees (UNHCR) estimates that the bulk of the "majority returnees" who wished to return have done so already. Minority returns are immeasurably more difficult, given the likely challenges to the social and material security of the returnees, and the possible threats to their physical security as well. Such returns are much more vigorously opposed by local authorities and others, who perceive the return of minorities as a threat to their political power base.

Implementation of property law has been regarded as the primary tool for the delivery of minority return. Since the Dayton Peace Accords, the property law regime has been substantially overhauled, with changes made to both the pre-war property framework and the wartime legal framework. The thrust since April 1998 has been implementation of those laws, in order to ensure that the displaced are able to return to their homes of origin, thus effectively undoing the ethnic cleansing that was so central to the Bosnian conflict.

This paper will explore the role of property law reforms and ensuing implementation in facilitating minority return in Bosnia and Herzegovina. It will first briefly address the phenomenon of mass displacement and the entanglement of the property system in Bosnia; it will then outline elements of the post-war property regime, and international efforts to establish a property regime in line with the annex 7 guaranteed right to return; and it will briefly explore the record of, and obstacles to, property law implementation. Finally, having reviewed the record of implementation, this paper will query whether there may be additional ways to help the displaced find durable solutions to their displacement, and the potential roles of the international community in such alternate solutions. It will argue that minority return, while still the best of the durable solutions available, is not the only solution, and that implementation of property law is not the only tool.

\section{Property and Mass Displacement}

Extensive wartime displacement unravelled elements of the pre-war property framework, leaving the majority of Bosnians in homes in which they had not been living before the war. Wartime authorities established new legal structures, in part to cope with the high level of displacement and the reality of thousands of displaced persons arriving in their communities, and also in many areas as a strategy of ethnic cleansing itself. In all parts of the country, municipalities developed systems to legally allocate abandoned property (under war-time laws), either on a temporary basis, which preserved the underlying ownership or "occupancy right"4 of the pre-war occupant, or permanently, stripping away the underlying rights.

While some housing was allocated on the basis of need, a substantial number of housing units were allocated through political patronage. Housing became a highly political resource used by the powerful to bestow "gifts" upon friends, political or military colleagues, and others of the "right" ethnicity. Thus professors, doctors, judges, government ministers, police, and many others received the "right," almost always in addition to maintaining their previous accommodation, to occupy a second flat, perhaps larger, or in a better neighbourhood.

This "multiple occupancy" was in some cases the result of families dividing after children married and started new families; in other cases, those "rewarded" with additional living space rented out that space and acquired a tidy profit. Local authorities were reluctant to evict these multiple occupants, particularly when they were political or other public figures. This phenomenon has proven a serious obstacle to the return of displaced persons.

In addition, throughout the country there were large numbers of "illegal occupants"-people in need of accommodation who moved into vacant property independently, without being legally allocated space by the municipality. In both entities of Bosnia-the largely Muslim-Croat "Federation," and the predominantly Serb Republika Srpskathe wartime legal provisions for property did not comply with the GFAP, or with the European Convention on the Protection of Human Rights and Fundamental Freedoms (ECHR). 5

During and since the war, all three groups have used property rights to cement the results of ethnic cleansing, erecting legal and administrative barriers in the way of return. The result is a highly complex and unsatisfactory property legal system, with elements of the old laws, war-time regulations, and the Dayton Agreement all vying for precedence ... ${ }^{6}$

The wartime property regimes in both areas are legitimate responses to the overwhelming humanitarian burden of housing huge flows of displaced persons throughout the country. Clearly, it made sense to reallocate empty housing to those in need. ${ }^{7}$ Yet, as shown, housing was not reallocated simply on humanitarian grounds, nor were the 
wartime laws applied in accordance with the letter of the law. Rather, application was highly discriminatory and served the political ends of nationalist parties. ${ }^{8}$

\section{Reconstruction of the Property Rights Regime}

Much of the energy of the international community since Dayton has been focused on returning displaced persons to their homes of origin, through the establishment of a new property regime, in compliance with annex 7 of the GFAP, and subsequently on implementing those laws. This has been a massive undertaking, involving substantial technical resources as well as a great deal of political will on the part of the international community.

The reform and implementation of laws giving effect to the right of refugees and displaced persons to abandoned property, as required by Annex 7 to the Dayton Agreement and the State and Entity Constitutions, has been one of the largest projects undertaken by $\mathrm{OHR}^{9}$ in the last two years. It has consumed the bulk of the field resources of RRTF $^{10}$ and the OSCE, ${ }^{11}$ it has been the subject of 14 Bonn Power ${ }^{12}$ decisions [now 24], and constitutes the bulk of the case load of human rights institutions and domestic courts. ${ }^{13}$

The result is a legislative regime that has been substantially reformed in both the Federation and Republika Srpska. Wartime laws, and contracts signed under those laws, were rendered void, and there is now new legislation and instruction in both entities that creates mechanisms for displaced persons to claim their property. The fundamental function of these laws was to elaborate a legal structure that would help refugees and displaced persons claim property that was theirs before the war, but is now occupied by someone else.

Political effort has been constructively directed at shaping legislation crucial to the reintegration process. In post-war Bosnia, nothing is as important as property rights ... ${ }^{14}$

\section{Implementation of Property Rights}

Implementation of property laws in both the Federation and Republika Srpska has progressed very slowly and generated precious few returns. Implementation of property law has now been underway for two and one-half years in the Federation and two years in Republika Srpska, with an approximate total of 175,000 claims filed. Results from a recent property-monitoring survey indicate that the percentage of claims resolved (in which prewar occupants were reinstated in their homes), versus the number of claims filed, was about 5 per cent nationwide: 6.5 per cent in the Federation; 1.6 per cent in the Republika Srpska. ${ }^{15}$ A sec- ond round of monitoring, completed in the spring of 2000, revealed a similarly poor rate of implementation.

There has been reluctance to implement the laws, even where implementation would be relatively easy, or at least free of negative humanitarian consequences. Multiple occupancy remains an issue largely unresolved throughout the country, ${ }^{16}$ and even reconstruction-related multiple occupancy has proven difficult to address. ${ }^{17}$ Reallocation continues in some areas, despite the legal prohibition against the practice.

Implementation has been least successful in Croatcontrolled areas of the Federation, particularly in Canton 7 and Canton 10. In some Croat municipalities, housing boards have still not been established (as in Drvar), and in others the housing board exists but has no staff (as in the Central Zone of Mostar). In Croat-controlled areas, evictions are extremely rare, and forcible evictions unheard of. At the moment, the international community seems stalled, unsure of what leverage, if any, can be utilized to promote implementation.

Implementation has also been abysmal in Republika Srpska. Local authorities refuse to evict anyone who cannot be offered alternative accommodation, and they generally discourage the return of Serb displaced persons to the Federation. Housing boards did not operate for the first three months in which the property laws were in place, and staffing remains a serious issue. The heads of numerous housing boards are themselves displaced persons, who have an interest in preventing return of minorities.

Implementation has been the most successful in Muslim-controlled areas of the Federation, particularly in Sarajevo, where there is, overall, a greater acceptance of minority return. The international community has been able to ally itself with progressive elements within the political leadership, and through establishment of the Sarajevo Housing Commission has successfully pushed for implementation of nearly 2000 decisions. Evicted families with no accommodation are being offered temporary accommodation, and the cantonal government has pledged to reserve a portion of funds generated through privatization of socially owned apartments for the construction of temporary housing.

\section{Obstruction of Property Law Implementation}

Municipal functionaries on all sides have developed a number of creative methods to obstruct implementation of the property laws. As some methods have been made more difficult through passage of amendments to the laws or through issuance of letters or instructions, municipal 
authorities have simply found new methods, including refusal to accept valid claims, if filed by mail, or by proxy (both of which are permitted by law); requiring documents not required by the laws; requiring current identification documents (even though pre-war documents are sufficient under the law); illegally charging fees, either for filing the claims, or for obtaining supporting documentation; insulting or abusing claimants; claiming lack of authority to decide certain types of claims (such as business premises); or requiring hearings, where it is clear that claimants will not be able to attend (i.e., they are refugees or displaced persons). In some areas, obstruction has been even more overt, and municipalities have simply failed to open the housing offices, opened them for very few hours per week, or understaffed them to the extent that claimants must wait interminably to be able to file their claims.

Obstruction by the housing offices has been supported in many cases by the police. According to recent instructions, police are required to attend all evictions and to provide security as necessary. However, throughout the country the police have been notorious for their lack of support for the property implementation effort, in part because numerous police officers are themselves beneficiaries of temporary accommodation, and some are multiple occupants.

\section{Obstacles to Implementation of the Property Laws}

Obstacles to implementation of the property laws are humanitarian and practical, as well as political obstacles, and the last are more difficult to address. These are linked, and those with political motivations are expert at harnessing the humanitarian concerns to suit their purposes.

\section{Humanitarian Obstacles}

Perhaps most significant of the humanitarian obstacles is the lack of alternative accommodation in Bosnia and Herzegovina. Approximately 25 per cent of the housing stock in the Rs was damaged, with a further 5 per cent completely destroyed; in the Federation, about half the housing stock was damaged, with 6 per cent destroyed. ${ }^{18}$ Despite significant efforts of the international community to reconstruct shelter, there is still a very real housing shortage. By necessity, implementation of the property laws and reinstatement of original owners or occupancy-right holders will require eviction of some who have no alternative accommodation. Under the Law on Refugees and Displaced Persons, local authorities are obliged, to provide adequate alternative accommodation to thosewith DP status who have been evicted. Having DP status prevents or stalls the eviction of many, because the authorities simply do not have the alternative housing stock.

Authorities are also reluctant to evict those who suffered particularly egregious losses. During the war, widows and families of killed soldiers were given preference in allocation of vacant housing stock, and their possible eviction, even where there is alternative accommodation, is a highly emotive issue for everyone. Political parties have avoided appearing to reject this constituency. There is also general reluctance to evict anyone who comes from areas where ethnic cleansing was most severe. Presently, in the Federation, virtually no housing boards are willing to evict families from the Eastern Republika Srpska, where ethnic cleansing was made famous in towns such as Zvornik, Bijeljina, and Srebrenica, even if the temporary occupants have property in these locations and theoretically could return. While these issues have been used to serve political ends, they are also genuine humanitarian obstacles in their own right.

From a practical perspective, there is the issue of twoway returns, or "reciprocity." Politicians argue that if "their people" are not able to return, they should not be obliged to let others return to the area, but this is raised here only as a practical consideration. Until returns are evident in all directions, blockages will arise that necessitate evicting people who have no alternative accommodation. While two-way returns clearly cannot be used as a rallying cry to delay action, they are a practical necessity in the absence of large-scale reconstruction projects, which would permit DPS to stay, either through buffer accommodation, or relocation projects.

Finally, a practical obstacle has arisen in some parts of the Rs, where some municipalities claim they do not have the resources to hire sufficient numbers of staff, or to train them adequately.

Elaborating upon the discussion of "multiple occupancy" above, it should be noted that when multiple occupants vacate housing units, space will be freed for people to return, but this on its own will not alleviate the housing shortage in Bosnia at present. The sheer level of damage to prewar units implies that the need for reconstruction remains great.

\section{Political Obstacles}

The underlying political reality in Bosnia is that return directly contravenes the goals of the leadership of both the Bosnian Croats in the Federation, and the Bosnian Serbs, ${ }^{19}$ and is seen as a threat to control over territory either acquired or defended during the war. ${ }^{20}$ That return is not supported from the top, and indeed is directly opposed, is the most significant barrier to property law implementation, 
manifesting itself in a variety of ways.

The major reason for the failure of return is opposition from nationalist leaders. Authorities at all levels and in all parts of the country have consistently obstructed return programmes ... Large scale minority return is opposed on all sides because it raises the possibility of losing control over territory gained or successfully defended during the war. ${ }^{21}$

Croat-controlled areas are led by the Croat Democratic Union (HDz), which was until January 2000 the party in power in Croatia. Extensive links between the Croatian and Bosnian arms of this party have been identified, according to the International Crisis Group (ICG), is key: identifying the HDz leadership in Zagreb, Croatia (not Mostar, Bosnia) as the locus of control, the ICG argues that "the backing which the $\mathrm{HDZ}$ in Bosnia receives from Zagreb makes it more resistant to international pressure ..." The ICG continues by saying that to "open" Croat-controlled areas of the Federation to return will require addressing the root of the issue, which is in Croatia. ${ }^{22}$

The integration of Bosnia and Herzegovina has been consistently obstructed by the main Bosnian Croat Party, the Croat Democratic Union of $\mathrm{BiH}$ (HDZBiH). The HDZBiH is dominated by hard-liners who emphasize the consolidation of a pure Croat-inhabited territory centred on Western Herzegovina, with the eventual aim of seceding and joining Croatia. ${ }^{23}$

Leadership in Republika Srpska is divided between the SLOGA ("Harmony") coalition, at the entity level, led by Prime Minister Milorad Dodik, and the sDs (the Serb Democratic Party, the former party of Radovan Karadzic "seen as hard-line opponents of Dayton"), ${ }^{24}$ which dominates at the municipal level (and thus controls the housing boards). While the sDs leadership is not as obstructionist as the HDz leadership in Croat-controlled parts of the country, there is a strong opposition to return of minorities to the Rs. The Bosnian-Croat allegiance to a notion of "Greater Croatia" is clearly parallel to Bosnian-Serb sentiment for a "Greater Serbia," although direct institutional links are less evident. Prime Minister Dodik, while sufficiently disassociated from the sDs hard line to have attracted support of the international community, has managed to deliver few returns for fear of radicalizing the electorate. At the local level, the sDs authorities retain a tight grip on the police forces, particularly in the Eastern Rs.

Even the Bosnian Muslims, who, unlike the Serbs or Croats, do not look to a "mother nation," are at best ambivalent and also obstruct minority returns to areas they control. ${ }^{25}$ Their interest is also in ethnic consolidation, but within the context of Bosnia defined as a multi-ethnic coun- try, and there is a strong desire to regain areas lost during the war, such as the Drina valley in the Eastern Rs. $^{26}$ They are interested in promoting returns from the areas they control, but not to the area they control, so they have encouraged returns of Bosniak DPs to areas in which they would be in a minority, in order to legitimate and secure territorial interests. There are recent indications that Bosniak returns to key strategic areas of the Rs, such as the Western Rs, have been at least tacitly supported by the Bosniak administration. ${ }^{27}$

... the right of return will ... continue to exacerbate the political contest of wills between the three parties, each obstructing return of displaced persons and refugees of other groups who would dilute their electoral base and are perceived as a threat to territorial sovereignty and national control. ${ }^{28}$

\section{Can Implementation of Property Law Deliver Minority Return?}

Based on what has been observed, it seems unlikely that anyone can expect property laws to be implemented soon, to deliver the minority return that is at the heart of the Dayton Peace Accords. Given the record of implementation and the magnitude of the political obstacles to return generally, and to property law implementation more specifically, it would be too optimistic to expect dramatic positive results in the foreseeable future. With an implementation rate of 1.6 per cent in the Rs and 6.5 per cent in the Federation, coupled with the utter failure of property law implementation in Croat-controlled areas, it appears that even the intense pressure levelled by the international community will be unable to push this forward soon enough for large numbers of displaced persons to make a commitment to return to their homes of origin. With the reality of at best stable-but more likely reduced-funding for international efforts, the ability to maintain or indeed increase the level of pressure on authorities to comply is unlikely to be indefinitely sustainable.

\section{Finding Durable Solutions for the Displaced}

For all of the efforts of the international community, some 836,000 people remain displaced within Bosnia, with a further 330,000 refugees still outside the country, without durable solutions. ${ }^{29}$ With five years having now passed since the DPA was signed, there is evidence that many families wish simply to normalize their conditions in their place of displacement, rather than to return to their homes of origin. As the implementation process is drawn out, they remain in limbo, fearful of being evicted from temporary 
accommodation, but unable to return.

International policy has worked on the assumption that the majority of displaced persons would want to return if human rights were respected and democratic values were in place. When people have expressed a wish not to return, this has not been seen as a genuine choice but indicative of systematic intimidation by nationalist politicians. ${ }^{30}$

There are indications that a substantial number of displaced persons do indeed wish to return to their homes of origin. There is also evidence, however, of a substantial minority who may be reticent to return, preferring to integrate with their present host community in Bosnia and Herzegovina, or another community within the country. In 1997, UNHCR and the CRPC carried out an extensive study of the attitude of displaced persons toward return..$^{31}$ While they found that the majority did indeed wish to return to their homes of origin, and would like once again to live among their pre-war neighbours, most preferred to do so in a context where their ethnic group controlled the municipal administration. People were much more hesitant to return to a context where they would clearly be in the minority. "[T]hey (also) see the prospect of living under the control of authorities of another ethnic group as the greatest threat to their security and livelihood." ${ }^{2}$

Many refugees, displaced by war, do not wish to return in the short term. Despite the desires of the international community, Bosnia in 1996, and even more so in 1998, was not the Bosnia of 1991. Many Serbs, Muslims, and Croats expressed the desire to stay elsewhere than return to their homes after the war... There are many reasons for this, which reflect the changes to the region since 1991, both political and economic. ${ }^{33}$

\section{Durable Solutions to Displacement}

The impasse between the moral necessity of opposing ethnic cleansing on the one hand, and the practical impossibility of achieving ethnic reintegration on the other, has left the international community in a period of strategic limbo, repeating resource intensive programmes that proved a consistent failure. ${ }^{34}$

UNHCR's concept of “durable solutions” to displacement includes return to home of origin; reintegration in the host country; resettlement in a third country; and relocation (settlement in country of origin in other than their preconflict home). These options, as already mentioned, are also guaranteed by annex 7 itself, which guarantees to displaced people the right to return, as well as the right to choose a new place to live. The international community in Bosnia has devoted the vast majority of its resources and energy to securing one option, while devoting insufficient attention to other options that might help "normalize" the lives of displaced persons. While the right to return should clearly be considered the first and best option, it should not be the only option. Indeed, if the international community considered supporting informed, voluntary, lawful relocation, in some cases, this might substantially contribute to implementation of property law, and secure the right of others to return.

Some returning refugees and displaced persons may decide to settle in their country of origin in a location other than their pre-conflict home: relocation. Not all populations displaced by conflict return to their homes following the end of hostilities. In addition to pre-conflict migration patterns, new migration patterns result from the social and economic upheaval stemming from conflict, the region's transition to a market economy, and other phenomena such as the move of rural populations to urban areas..$^{35}$

UNHCR has identified a number of different forms of relocation: (1) voluntary relocation, which is based on informed choice, and respects the property rights of others, (2) passive relocation, in which displacement violates the property rights of others and becomes a permanent condition, and (3) hostile relocation, in which groups of people are deliberately placed in housing that belongs to other groups, in order to consolidate territorial control and prevent minority returns. ${ }^{36}$ It should go without saying that the only form of relocation advocated here is the truly voluntary one, based on informed choice, that does not infringe upon the right of others to return. ${ }^{37}$

An element of voluntary relocation of population is an inevitable part of post-war recovery. As the international assistance operation shifts in modality from humanitarian to development assistance, the normalization of living conditions must be a priority. Voluntary relocation that occurs through lawful transactions of property may present the best possibility for relieving pressure on the housing situation, and may prove complementary to existing return efforts. ${ }^{38}$

There are several ways in which voluntary relocation could be supported, which vary in their degree of intervention. These include strengthening the role of the CRPC to include facilitating the sale and exchange of property, and providing RRTF funding for urban relocation projects that do not violate property rights and are administered without discrimination. ${ }^{39}$ It would be essential to ensure that transactions are voluntary, and that people are provided by the media with maximum information about their options. 


\section{Strengthening the Role of the CRPC}

The Commission for Real Property Claims (CRPC) was established under annex 7 of the Dayton Accords to render final and binding certificates for title to both private and socially owned property. This legal power is independent of administrative and court processes and is particularly useful where title is contested. Until now, the CRPC has issued only certificates of ownership. However, by the very nature of its work, the commission is also well placed to facilitate property changes among people with proof of ownership. Indeed, in its study on property rights, the CRPC noted that claimants frequently request that it provide this service. ${ }^{40}$ Such a service would allow those who are not yet ready to return-but who would like to exchange their property with someone in the other entity - to do so; or if they wish to sell their property, to sell it in a legal and straightforward manner. The CRPC could also help to sell the properties for those who have settled permanently abroad. Such an undertaking would simultaneously provide refugees with resources to help them settle in the host country, and would free up needed housing space in Bosnia. Because of the unique position of the CRPC, it could usefully expand into this area. ${ }^{41}$

\section{Providing RRTF Funding for Urban Relocation Projects}

The Return and Reconstruction Task Force does not encourage the funding of relocation projects, whether they are voluntary or not. However, to fund select voluntary relocation projects in each major urban centre in Bosnia would accommodate displaced persons living in claimed accommodation and slated for eviction-people who are genuinely unable to return to their home of origin (because it is severely damaged, or for security reasons), who may be presently employed and successfully integrating into their new community. This would simultaneously free up occupied housing space in those municipalities, and support return. Such accommodation could be provided to evicted displaced persons on a rental basis.

In its study, the CRPC notes that, as in any effort that supports voluntary relocation, it would be essential that displaced persons be provided with the most accurate information available, ${ }^{42}$ and that they not be manipulated by their political leaders. It would also be essential that the local press continue to be monitored in order to assess "information" produced by political parties.

Neither of these suggestions is envisaged as a substitute for focusing on minority return through implementation of property law, but as parallel efforts that would help some people find solutions to their displacement, while contributing to reducing the blockage in property implementation generally.

\section{Conclusions}

This paper has explored the post-Dayton property regime in Bosnia, as one tool that facilitates return of displaced persons and refugees. Against a brief review of the legal framework, this paper has discussed the implementation record to date on post-Dayton property laws intended to facilitate return. It has been found that few successes can be recorded. Humanitarian and political obstacles, exemplified in a multitude of mundane obstructive tactics, have resulted in few minority returns. Reformed property lawsthe subject of much attention and the primary drain on resources of the international community-have yet to return significant numbers of displaced persons to their homes.

The paper has concluded by arguing that the international community must expand its focus beyond minority return, to the broader concept of "durable solutions," and thus expand strategies beyond property law implementation. Acknowledging that some displaced persons will not wish to return to their home of origin, the international community should engage in parallel efforts to provide solutions to those who genuinely wish to relocate. Such efforts would not only help normalize living conditions for a wider range of people, but would likely also assist in breaking the blockage in property law implementation.

\section{Endnotes}

1. Chapter 1, article 1, annex 7 ("Agreement on Refugees and Displaced Persons") of the General Framework Agreement for Peace.

2. The Office of the High Representative interpreted the homes of origin provision of annex 7 of the Dayton Accords to mean the right to return to the housing unit in which one lived before the war. UnHCR, "1998 Presentation by UnHCR," Property and Housing Issues Affecting Repatriates and Displaced Persons in Bosnia and Herzegovina (compilation of material assembled by OHR for Property Law Training Workshops), 27 (4).

3. Of the approximately 2.2 million displaced people at the end of the war, 1.2 million were refugees, while approximately 1 million were displaced within the borders of Bosnia. International Crisis Group (ICG), Going Nowhere Fast: Refugees and Internally Displaced Persons in Bosnia, International Crisis Group (ICG) Bosnia Project, April 30, 1997, p. 8.

4. Pre-war Yugoslavia had several types of property, including what is referred to as socially owned property, a form of property entitlement that is stronger than a rental arrangement, but weaker than private property rights. 
5. Article 1, protocol 1 of the EHCR states, "Every natural or legal person is entitled to the peaceful enjoyment of his possessions. No one shall be deprived of his possessions except in the public interest and subject to the conditions provided for by law and by the general principles of international law."

6. Marcus Cox, Strategic Approaches to International Intervention in Bosnia and Herzegovina (Geneva: CAsIn, 1998), 38, 39.

7. OHR, Refugee Return through Property Laws: Briefing Paper (Sarajevo: ohr, August 1999), 1.

8. CRPC/UnhCr, Return, Relocation, and Property Rights: A Discussion Paper, (Sarajevo: CRPC/UnHCR, December 1997), p. 8.

9. Under annex 10 of the Dayton Peace Accords, the Office of the High Representative (OHR) is the lead agency in Bosnia that deals with civilian aspects of peace implementation. The oHR was given the task at Dayton to mobilize and coordinate the activities of agencies involved in the civilian aspects of the peace settlement. The Peace Implementation Council has the power to expand or develop the powers of the High Representative.

10. The international community has developed an elaborate structure and process to encourage those who are still displaced to return to their home of origin, and has focused with particular intensity on minority returnees. Through the Return and Reconstruction Task Force (RRTF), which is led by the oHR but supported also by the UNHCR and other agencies, the international community has sought to promote return by addressing issues of "space, security and sustainability." In contending with "space," the RRTF has focused on encouraging implementation of the property laws by pressuring and encouraging local officials, to ensure that minorities are once again given access to their property. The RRTF has also played a fundamental role in identifying "axes of return" throughout Bosnia, directing donor funding to areas where minority return is underway or likely to commence.

11. Oganization for Security and Cooperation in Europe.

12. The Bonn Powers are enumerated in chapter 11, paragraph 2 of the Bonn PIC Declaration, which states in part, "The Council welcomes the High Representative's intention to use his final authority ... to facilitate the resolution of difficulties by making binding decisions as he judges necessary."

13. OHR, Refugee Return through Property Laws, 1.

14. David L. Bosco, "Reintegrating Bosnia: A Progress Report," The Washington Quarterly (Spring 1998), 76.

15. OHR, Refugee Return through Property Laws, 4 .

16. ICG, in its report Rebuilding a Multi-Ethnic Sarajevo: The Need for Minority Returns, ICG Bosnia Project, February 3, 1998, indicates that about 5000 homes in Sarajevo Canton are occupied by people who have access to alternative housing" p.7.

17. This occurs where temporary occupants are beneficiaries of a reconstruction project, but continue to occupy other housing. This may be because they have a job in the area of the home they occupy, or may simply be because they prefer to have two accommodations.

18. ICG, Going Nowhere Fast, 11.

19. Bosco, Reintegrating Bosnia, 70; see also Jane M. O. Sharpe, "Dayton Report Card," International Security 22 (3): 4.

20. Chaloka Beyani, "A Political and Legal Analysis of the Problem of Return of Forcibly Transferred Populations," Refugee Survey Quarterly, 6 (3): 4.

21. Cox, Strategic Approaches, 28, 29.

22. ICG, Minority Return or Mass Relocation? 43.

23. ICG, Changing Course? The Implications of the Divide in BosnianCroat Politics, ICG Bosnia Project, August 13, 1998.

24. David Chandler, Bosnia: Faking Democracy after Dayton (London: Pluto Press, 1999), 75.

25. An example is documented by ICG in their report, A Tale of Two Cities: Return of Displaced Persons to Jajce and Travnik, ICG Bosnia Project, June 3, 1998. The HDZ administration in Jajce has been generally obstructive of Bosniak returns to the town. The sDA administration in Travnik has obstructed returns to Travnik, but relatively supportive of returns by Muslims from Travnik to other parts of the country.

26. European Stability Initiative (ESI), Reshaping International Priorities in Bosnia and Herzegovina: Bosnian Power Structures (Brussels: ESI, 14 October 1999), 15.

27. Chandler, Bosnia: Faking Democracy, 107.

28. Susan Woodward, "Bosnia after Dayton: Year Two," Current History 96 (608): 103.

29. UNHCR, Refworld, www.unHCR.ch/world/euro/bosnia.htm (October 9, 1999).

30. Chandler, Bosnia: Faking Democracy, 104.

31. CRPC/UnHCR, Return, Relocation and Property Rights, 19. This study involved a survey of 862 displaced persons in $\mathrm{BiH}$, and 683 refugees in Croatia and the Federal Republic of Yugoslavia. The survey was complemented by a series of focus groups held with refugees and displaced persons.

32. Cox, Strategic Approaches, 29.

33. Chandler, Bosnia: Faking Democracy, 105.

34. Cox, Strategic Approaches, 42.

35. UNHCR, UNHCR Note on Returns from Germany to Internal Displacement in Bosnia and Herzegovina (UNHCR: Sarajevo, July 1998), paragraph 3.4.

36. UNHCR, Repatriation and Return Operation 1998 (UNHCR: Sarajevo, 1998), 3, 4 .

37. Relocation has been used unscrupulously by some European governments as well as by municipal governments. Numerous Laender in Germany (which, according to UNHCR, establish their own criteria for termination of temporary protection and refugee deportation), for example, have supported relocation in violation of underlying property rights. For example, relocation projects in Sanski Most and Bosanski Krupa in Canton 1 have involved the reconstruction of houses owned by displaced Serbs, for the continued residence of the Muslim DPs. Municipal governments have in some cases extended themselves to attract this kind of "assistance," preferring to keep the DPs (who are of the same ethnicity and hence more apt to vote for them) than to promote return of minorities (who are less likely to vote for them). Municipalities have also been involved in supporting relocation projects by offering empty municipal land for the purpose- this is not itself a problem, but where that land was used for cultural, social, or religious purposes before the war, such relocation would be in violation of a High Representative Decision of May 26, 1999, intended to ensure that land previ- 
ously used by minorities is not reallocated.

38. CRPC/UNHCR, Return, Relocation, and Property Rights, 1.

39. Elsewhere I have seen references to establishing a compensation mechanism, as is foreseen in annex 7 of Dayton and in the mandate of the CRPC. I have not listed it here because it seems an unlikely strategy in a context where there are few internal resources to invest in such an enterprise, and where international agencies clearly do not intend to provide resources either. Any scheme based on vouchers or coupons seems unwieldy and impracticable.

40. CRPC/UnHCR, Return, Relocation, and Property Rights, 25.

41. Ibid., 26.

42. Ibid., 25 .

Lene Madsen worked for two years in Bosnia and Herzegovina on issues related to property and return, first as a protection officer for the UNHCR, then as head of the Human Rights Coordination Centre, based within the Office of the High Representative. 